\title{
FCGR2C wt Allele
}

National Cancer Institute

\section{Source}

National Cancer Institute. FCGR2C wt Allele. NCI Thesaurus. Code C51392.

Human FCGR2C wild-type allele is located in the vicinity of 1 q23.3 and is approximately 15 $\mathrm{kb}$ in length. This allele, which encodes low affinity immunog lobulin gamma Fc region receptor II-c protein, plays a role in cellular responses, and in the modulation of B-cell antibody production. 